\title{
THE EFFECT OF PLANTING SPACE AND LEVEL OF PHOSPHOR FERTILIZER DOSE ON GROWTH, DRY MATTER YIELD, AND CRUDE PROTEIN CONTENT OF Indigofera arrecta
}

\author{
T. Akbarillah and Hidayat \\ Faculty of Agriculture, Bengkulu University \\ Jl. WR Supratman, Kandang Limun Bengkulu, 38371 - Indonesia \\ Corresponding Email: tris_akbarillah@unib.ac.id \\ Received November 12, 2009; Accepted May 02, 2010
}

\begin{abstract}
Study on Indigofera arrecta has not been explored widely yet. Therefore, its growth characteristic and its nutritive value need to be studied. The research was conducted to evaluate growth characteristic and its nutritive value of Indigofera arrecta planted on different planting spaces and different levels of NPK fertilizer dose. Two factors experiments were assigned in a Split-Plot Design. The first factor (A) was planting space, (1) $50 \times 50 \mathrm{~cm}$ and (2) $75 \times 75 \mathrm{~cm}$. The Second factor (B) was level of fertilizer dose, (1) $0 \mathrm{~kg} \mathrm{P}_{2} \mathrm{O}_{5} / \mathrm{ha}+100 \mathrm{~kg} \mathrm{~K} \mathrm{~K}_{2} \mathrm{O} / \mathrm{ha}$, (2) $100 \mathrm{~kg} \mathrm{P}_{2} \mathrm{O}_{5} / \mathrm{ha}+100 \mathrm{~kg} \mathrm{~K} 2 \mathrm{O} \mathrm{kg} / \mathrm{ha}$ and (3) $200 \mathrm{~kg}_{2} \mathrm{O}_{5}+100 \mathrm{~kg}$ $\mathrm{K}_{2} \mathrm{O} /$ ha. The results showed that planting space had no effect on height of plant $(\mathrm{P}>0.05)$ but diameter of stem were statistically different $(\mathrm{P}<0.05)$. In addition, their dry matter yield and crude protein content were not different $(\mathrm{P}>0.05)$ on either planting space or $\mathrm{P}$ fertilizer dose. There were no interaction between planting space and $\mathrm{P}$ fertilizer dose. In addition, there were no effects either planting space or $\mathrm{P}$ fertilizer dose on dry matter edible part, crude protein content, and plant height. Indigofera arrecta planted on wider planting space produce bigger stem diameter and bigger number of branch.

Keywords: Indigofera, nutritive value, phosphor, planting, space yield
\end{abstract}

\section{INTRODUCTION}

Indigofera arrecta is one of kind browse leguminous plant, growing erect, woody stem as animal feed, and slopping plant to prevent erosion. This plant has 5-8 pairs leaflet, green color and its height reached $2 \mathrm{~m}$. (Andrews, 1952 cited by Skerman, 1977). The leaf of Indigofera arrecta is similar to the leguminous plant, containing high crude protein, $\beta$-carotene and xanthophylls. The Indigofera leaf supplementation on duck and quail resulted high Yolk Color Score (Akbarillah et al., 2002, 2005).

The leguminous plant needs a large amount of phosphor for nodulation and nitrogen fixation Skerman (1977) reported that the amount of legume nodule increased a long with increased phosphor availability. The number of nodule density (the nitrogen fixation part by rhizobium) and Nitrogen fixation velocity are stimulated by phosphor.

Planting space affects plant growth stage. Short distance (increased density) increases nutrient requirement and sunlight competition. In addition, increasing density affected environment temperature and humidity. The change of environment temperature will affect growth and plant metabolism (Van Soest, 1994). Increasing environmental temperature affects biochemistry process. Increasing cell temperature cause velocity of activation (vibration, rotation and translation) so that molecule reaction is faster. Increasing temperature and stimulation of temperature will damage structure and velocity of reaction (Fitter and Hay, 1994). Plant converts photosynthesis product to be structural component faster along with increasing temperature. The forage growing on the land with higher temperature has higher legum of plant cell wall and faster metabolic activity, therefore pool metabolic in the cell is decreased (Van Soest, 1994). Plant needs certain air humidity for the life. Air humidity affects physiology process of plant. High air humidity inhibits transpiration process. Transpiration is important in mineral transportation from rod to other parts of plant such as leaf. Plants response variable temperature and water for shoot weight, root weight, shoot/root ratios and number of roots (Kendall et al., 2006). Light is needed for photosynthesis 
process. Amount of light required by a plant depends on the light quality, wavelength and light intensity (amount of light per $\mathrm{cm}^{2}$ per second and its duration (Dwidjoseputro, 1978). The light affects growth, production and chemical composition of forage. Light is restricted factor on forage growth in shading land (Akbarillah et al., 2002). Study by Akbarillah et al. (2002) showed that the spacing $1.5 \mathrm{mX} 1.5 \mathrm{~m}$ resulted the highest forage production $(\mathrm{P}>0.05)$ per area unit while the spacing $3.5 \mathrm{mX} 3.5 \mathrm{~m}$ had the forage production per plant. Percentage of utilization of native herbage dropped as forage of the woody species increased (Ainalis and Tsiouvaras, 2004).

Indigofera arrecta in early stage planted in the different shading area showed difference growth characteristic (Akbarillah et al., 2002). The research was conducted to evaluate dry matter production, crude protein content of Indigofera arrecta planted on certain planting space and dose of Phosphor fertilizer. The research was expected to contribute on optimal land usage especially on availability of ruminants feed to support agro forestry and integrated sustainable farming system.

\section{MATERIALS AND METHODS}

\section{Experimental Design}

The experimental design on the research used a split plot design (Gomez and Gomez, 1984). The main plot was planting space $50 \mathrm{~cm} \mathrm{X}$ $50 \mathrm{~cm}$ and $75 \mathrm{~cm} \mathrm{X} 75 \mathrm{~cm}$ and the sub plot was dose of phosphor fertilizer. Fertilizer used was super phosphate contain $36 \% \quad \mathrm{P}_{2} \mathrm{O}_{5}$ and $\mathrm{KCl}$ contain $60 \% \mathrm{~K}_{2} \mathrm{O}$. The treatment dose of fertilizer were (1) $0 \mathrm{~kg} \mathrm{P}_{2} \mathrm{O}_{5} / \mathrm{ha}+100 \mathrm{~kg} \mathrm{~K} 2 \mathrm{O} / \mathrm{ha}$., (2) $100 \mathrm{~kg}$ $\mathrm{P}_{2} \mathrm{O}_{5} / \mathrm{ha}+100 \mathrm{~kg} \mathrm{~K} \mathrm{~K}_{2} \mathrm{O} \mathrm{kg} / \mathrm{ha}$ and (3) $200 \mathrm{~kg}$ $\mathrm{P}_{2} \mathrm{O}_{5}+100 \mathrm{~kg} \mathrm{~K}$ O/ha.

The plants used were 1 year old Indigofera arrecta. They were planted by planting space 50 $\mathrm{cm} \mathrm{X} 50 \mathrm{~cm}$ and $75 \mathrm{~cm} \mathrm{X} 75 \mathrm{~cm}$. The plants were initially fertilized with organic fertilizer in equal dose. Every planting space was treated 3 doses of fertilizer. Every dose had 4 replications. Initial cutting was done at $60 \mathrm{~cm}$ plant height. Area signed with number and code by colored plastic. Fertilizing as in hole of soil and covered it with soil (side dressing). The observation started after initial cutting and ended after 12 weeks.

\section{Parameter measured}

Parameter measured were plant height $(\mathrm{cm})$, number of branch, stem diameter $(\mathrm{cm})$ dry matter production and crude protein content $(\%)$ of Indigofera arrecta harvested by cutting stem on $60 \mathrm{~cm}$ plant height and branch was cut at $5 \mathrm{~cm}$ long after 12 weeks observation.

Harvested part classified to edible part (the parts of plant that animal would eat these were leaf and stem diameter less than $6 \mathrm{~mm}$ ) and inedible part. Parts that were not eat by animal, these were stem having diameter more than 6 $\mathrm{mm}$ ). After Indigofera arrecta weighed, the sample of Indigofera arrecta was dried using force air circulation oven at $45^{\circ} \mathrm{C}$ for two days, and samples were then weighed. Dry samples were ground on screening diameter $1 \mathrm{~mm}$ for chemical analyses (dry matter and crude protein content, AOAC,1976).

\section{Data Analysis}

The data were analyzed using Analysis of Variance, if the result were significant different they were continued by Duncan's Multiple Range Test (DMRT) (Gomez and Gomez, 1984).

\section{RESULT AND DISCUSSION}

The research showed that the characteristics of Indigofera arrecta planted at different planting space $50 \mathrm{~cm} \mathrm{X} 50 \mathrm{~cm}$ and $75 \mathrm{~cm} \mathrm{X} 75 \mathrm{~cm}$ were not significant different $(\mathrm{P}>0.05)$ on plant height (Table 1). Nevertheless, stem diameter and number of branch showed significant effect $(\mathrm{P}<0.05)$. Wider planting space caused growth media to be more spacious, therefore nutrient in the soil and light were more available. As a result, diameter and height of plant growth as well as plant branch increased. Plant growth was affected by environmental factors such as temperature, humidity, nutrients, and light (Chen, 1990; Ong and Mathuya, 1992; Saini and Misra, 1992). Planting space affected micro environment (temperature, humidity and light) and expanded the rod to uptake nutrient. In this case, both of planting space were not enough to influence of micro environment, especially on nutrient uptake and light competition. In contrast, stem diameter and number of branch were affected by planting space $(\mathrm{P}<0.05)$. Planting space affected micro climate environment to plant, therefore it increased more number of branch and wider stem diameter.

The increasing level of phosphor fertilization used did not affect Indigofera arrecta growth characteristic (height, stem diameter and number of branch). There were no interaction between 
Table 1. The Average of Plant Height, Stem Diameter and Number of Branch Indigofera arrecta

\begin{tabular}{|c|c|c|c|}
\hline Treatment & $\begin{array}{c}\text { Height } \\
(\mathrm{cm} / \text { plant })\end{array}$ & Diameter & $\begin{array}{c}\text { No of } \\
\text { Branches }\end{array}$ \\
\hline \multicolumn{4}{|c|}{ Planting space (the effect of plot) } \\
\hline A $1(50 \times 50 \mathrm{~cm})$ & 146.22 & $0.22 \mathrm{a}$ & $8.80 \mathrm{a}$ \\
\hline A $2(75 \times 75 \mathrm{~cm})$ & 146.42 & $0.32 b$ & $16.80 \mathrm{~b}$ \\
\hline Significance & ns & $*$ & $* *$ \\
\hline \multicolumn{4}{|c|}{ Fertilizing (the effect of sub plot) } \\
\hline B1 (0 kg P2O5/ha) & 145.73 & 0.24 & 11.7 \\
\hline B2 (100 kg P2O5/ha) & 145.93 & 0.26 & 11.8 \\
\hline B3 (200 kg P2O5/ha) & 147.3 & 0.31 & 14.9 \\
\hline Significance & $\mathrm{ns}$ & ns & $\mathrm{ns}$ \\
\hline \multicolumn{4}{|c|}{ Plant space $\mathrm{x}$ Fertilizing } \\
\hline A1B1 & 146.7 & 0.19 & 8.4 \\
\hline $\mathrm{A} 1 \mathrm{~B} 2$ & 145.4 & 0.19 & 7.9 \\
\hline A1B3 & 145.55 & 0.29 & 10.1 \\
\hline $\mathrm{A} 2 \mathrm{~B} 1$ & 144.75 & 0.29 & 15 \\
\hline $\mathrm{A} 2 \mathrm{~B} 2$ & 146.45 & 0.33 & 15.7 \\
\hline A2B3 & 148.05 & 0.31 & 19.7 \\
\hline Significance & ns & $\mathrm{ns}$ & $\mathrm{ns}$ \\
\hline
\end{tabular}

Different superscript at the same column is statistically different $(\mathrm{P}<0.05), \mathrm{ns}=$ non significance $(\mathrm{P}>0.05)$,

$*=$ significance $(\mathrm{P}<0.05), * *=$ significance $(\mathrm{P}<0.01)$

Table 2. The Average of Dry Matter Part and Crude Protein Content of Indigofera arrecta on Different Planting Space and Phosphor Fertilizing Dose

\begin{tabular}{lcc}
\hline \multicolumn{1}{c}{ Treatment } & $\begin{array}{c}\text { Height } \\
(\mathrm{cm} / \text { plant })\end{array}$ & Diameter \\
\hline \multicolumn{2}{c}{ Planting space (the effect of plot) } & \\
A1 (50x50 cm) & 665.94 & 23.12 \\
A2 (75x75 cm) & 615.64 & 23.74 \\
Significance & $\mathrm{ns}$ & $\mathrm{ns}$ \\
\hline Fertilizing (the effect of sub plot) & \\
B1 (0 kg P2O5/ha) & 587.51 & 22.96 \\
B2 (100 kg P2O5/ha) & 633.74 & 23.38 \\
B3 (200 kg P2O5/ha) & 701.11 & 24.45 \\
Significance & $\mathrm{ns}$ & $\mathrm{ns}$ \\
\hline Plant space x Fertilizing & & \\
A1B1 & 607.68 & 22.91 \\
A1B2 & 692.43 & 23.40 \\
A1B3 & 697.70 & 24.02 \\
A2B1 & 567.34 & 23.01 \\
A2B2 & 575.06 & 23.35 \\
A2B3 & 575.06 & 24.87 \\
Significance & $\mathrm{ns}$ & $\mathrm{ns}$ \\
\hline
\end{tabular}

$\mathrm{ns}=$ non significance $(\mathrm{P}>0.05)$ planting space and dose of fertilizer $(\mathrm{P}>0.05)$. Phosphor fertilizing in condition where rain fall was $67.83 \mathrm{~mm} /$ month, temperature was $29^{\circ} \mathrm{C}$ and air humidity was $78.53 \%$, cause restricted water availability. The rod absorption of phosphor was therefore inhibited. As a result, the growth was not optimal (Akbarillah et al., 1999), physiology and morphology of plant activity was disturbed by limited water availability (Dwidjoseputro, 1978). There was no interaction between treatments on plant height, stem diameter and number of branch $(\mathrm{P}>0.05)$.

The dry matter production, included leaf and branch as animal consumed (edible part) can be seen on Table 2. Density of plants caused by difference planting space did not affect dry matter production of leaf and branch, as animal consumed (edible part) $(\mathrm{P}>0.05)$. Planting space should be distinguished competition stage for nutrient and light. Eventhough there were not statistically difference, there were tendency that longer planting space produced higher dry matter biomass per plant. Nevertheless, if the dry matter production converted in to production per square space, shorter plant space produced higher biomass as a result number of population per square space increased. Increasing number of plant population per square space would cause higher dry matter production. (Akbarillah et al., 2005). The result of this research was higher than the result reported by Akbarillah et al. (2005). Akbarillah et al. (2005) reported that Indigofera fertilized by organic fertilizer produced dry matter of edible part in average as $209.62 \mathrm{~g} / \mathrm{m}^{2}$ and $290.26 \mathrm{~g} / \mathrm{m}^{2}$ on planting space $50 \times 50 \mathrm{~cm}$ and $75 \times 75 \mathrm{~cm}$, respectively. Hassen et al. (2006) explained that dry matter production of Indigofera arrecta was $272.8 \mathrm{~g} / \mathrm{m}^{2}$ in the first year, the production of dry matter reached 1662 $\mathrm{g} / \mathrm{m}^{2}$ in second year. Dry weight shoot of Indigofera arrecta fertilized with $90 \mathrm{~kg} / \mathrm{ha} \mathrm{P}_{2} \mathrm{O}_{5}$ and fertilizer base of $110 \mathrm{~kg} / \mathrm{ha} \mathrm{K}_{2} \mathrm{O}$ and $55 \mathrm{~kg} / \mathrm{ha}$ $\mathrm{N}$ was $451.09 \mathrm{~g} / \mathrm{m}^{2}$ at planting space $50 \times 50 \mathrm{~cm}$ and $178.32 \mathrm{~g} / \mathrm{m}^{2}$ at planting space $75 \times 75 \mathrm{~cm}$ (Siddiqui et al., 2007).

Consistent with addition plant height and stem diameter, fertilizing dose had no significant effect $(\mathrm{P}>0.05)$ on dry matter edible part. This result might be caused by climate condition which was not appropriate, such as low rainfall (67 $\mathrm{mm} /$ month) and environment temperature $29^{\circ} \mathrm{C}$, whereas Siddiqui et al. (2007) did intercultural operation and irrigation as necessary.

Crude protein content of Indigofera arrecta 
was not affected by treatment planting space and phosphor dose. Planting space and phosphor dose more affected on biomass yield (Akbarillah et al., 2005). Protein content of leguminous crop leaves are rarely affected by agronomic and management practices. On the other hand, agronomic and management practices may effectively affect on protein content of grass species.

\section{CONCLUSION}

It can be concluded that there was no interaction between planting space and $\mathrm{P}$ fertilizer dose. In addition, there were no effects either planting space or $\mathrm{P}$ fertilizer dose on dry matter edible part, crude protein content, and plant height. Indigofera arrecta planted on wider planting space produced bigger stem diameter and bigger number of branch.

\section{REFFERENCES}

Ainalis, AB. and C.N. Tsiouvaras, 2004. Forage production of woody fodder species and herbaceous in silvopastoral system in Northern Greece. Agroforestry System 42 (1):1-11. DOI : 10.1023/A:1006112330453

Akbarillah, T., S.P.S. Budi and B.P. Widyobroto, 1999. Produksi, Kecernaan In vitro dan In sacco Hijauan legum di Lahan Perkebunan Karet Pada Umur Yang Berbeda. J. Agrosains. 12 (2):103-110

Akbarillah, T., Sutriyono, Nugraha, D.A. and Hidayat. 2002. Growth characteristics of Indigofera arrecta under different shading level. Proceedings: The $3^{\text {rd International }}$ Seminar on Tropical Animal Production, 1516 October 2002, Gadjah Mada University, Yogyakarta. Page 43-49

Akbarillah, T., Yulmaida and Hidayat. 2005. Produksi Hijauan Indigofera (Indigofera arrecta) pada Jarak Tanam dan Interval Pemotongan yang Berbeda. Prosiding. Seminar Nasional. Pengembangan Usaha Peternakan Berdaya Saing di Lahan Kering. Fakultas Peternakan UGM, Yogyakarta. 120-
127

AOAC. 1976. Official Methods of Analysis. 11 $1^{\text {th }}$ Ed. AOAC, Washington, DC.

Chen, C.P. 1990. Management of Forage for Animal Production Under Tree Crops, Integrated Tree Cropping And Small Ruminant Production System. Proceeding of Workshop on Research Methodologies. Medan. North Sumatera Indonesia. Page 1023

Dwijoseputro, D. 1978. Pengantar Fisiologi Tanaman. Penerbit PT Gramedia, Jakarta. p. $11-15 ; 89-96$

Fitter, A.H. and R.K.M. Hay,. 1994. Fisiologi Lingkungan Tanaman. Gadjah Mada University Press. Yogyakarta

Gomez, K.A and A.A. Gomez. 1984. Statistical Procedures for Agricultural Research. $2^{\text {nd }} \mathrm{Ed}$. An International Rice Research Institute Book. John Wiley \& Sons.

Hassen, A. N.F.G. Rethman, Z. Apostolides and W.A.V. Niekerk. 2008. Forage production and potential nutritive value of 24 shrubby Indigofera accessions under field condition in South Africa. Trop. Grassland 42: 96-103.

Kendall, W.A., J.A. Shaffer, and R.R. Hill Jr. 2006. Effect of temperature and water on the juvenile growth of lucerne and red clover. Grass and Forage Science 49 (3): 264-269. DOI: $10.1111 / \mathrm{j} 1365-2494 / \mathrm{t} 602000$.

Ong C.K. and M. Mathuya. 1992. Trees and Crops. Agroforestry today. 4(2): 11

Saini B.C. and K.K. Misra, 1992. With Two Crops, Can You Also Grow Trees? Agroforestry Today. 4 (1): 17

Siddiqui, A.T.S.U.A., A.K.M.M. Hossin, M.M. Rahman and S.M. Sayem. 2007. Effect of Phosphorus on growth and nodule formation of Indigo plant under old Himalayan Piedmont Field condition. Int. J. Sustain. Crop. Prod. 2(6):21-24

Skerman, P.J. 1977. Tropical Forages Legumes. FAO. Rome.

Van Soest, P.J. 1994. Nutrional Ecology of Ruminant. $2^{\text {nd }}$ Ed. Cornell University Press. Ithaca, New York. 